\title{
Different Outcomes in the Reactions of $\mathrm{WCl}_{6}$ with Carboxylic
}

\author{
Acids \\ Marco Bortoluzzi ${ }^{a}$, Federica Guarra ${ }^{b}$, Fabio Marchetti ${ }^{\text {b,* }}$, Guido Pampaloni ${ }^{\text {b }}$, \\ Stefano Zacchini ${ }^{\mathrm{c}}$ \\ a Università di Venezia Ca' Foscari, Dipartimento di Scienze Molecolari e Nanosistemi, \\ Dorsoduro 2137, I-30123 Venezia \\ ${ }^{b}$ Università di Pisa, Dipartimento di Chimica e Chimica Industriale, Via Moruzzi 13, I-56124 \\ c Dipartimento di Chimica Industriale "Toso Montanari”, Università di Bologna, Viale \\ Risorgimento 4, I-40136 Bologna, Italy
} Pisa, Italy

Received.......; accepted

* Corresponding author. Tel.: +390502219245. E-mail address: fabio.marchetti1974@unipi.it Webpage: http://www.dcci.unipi.it/fabio-marchetti.html 


\begin{abstract}
The reactions of $\mathrm{WCl}_{6}$ with a selection of carboxylic acids were investigated by using dichloromethane as reaction medium. The addition of pyridine-3-carboxylic acid (niacin) to $\mathrm{WCl}_{6}$ gave $\left[\mathrm{C}_{5} \mathrm{H}_{4} \mathrm{NHC}(\mathrm{O}) \mathrm{Cl}\right]\left[\mathrm{WOCl}_{5}\right], \mathbf{1}$, in $75 \%$ yield via selective $\mathrm{Cl} / \mathrm{O}$ interchange. $\mathrm{WCl}_{6}$ reacted with $\mathrm{RCO}_{2} \mathrm{H}\left(\mathrm{R}=\mathrm{CH}_{3}, \mathrm{CBr}_{3}, \mathrm{CHCl}_{2}\right)$ in $1: 2$ ratio resulting in the formation of $\mathrm{HCl}$ and the respective acyl chlorides, $\mathrm{RC}(\mathrm{O}) \mathrm{Cl}$. $\mathrm{WOCl}_{4}\left(\kappa^{1}-\mathrm{CH}_{3} \mathrm{CO}_{2} \mathrm{H}\right), 2$, was isolated from $\mathrm{WCl}_{6} / \mathrm{CH}_{3} \mathrm{CO}_{2} \mathrm{H}$ in $41 \%$ yield. The 1:2 reaction of $\mathrm{WCl}_{6}$ with $\mathrm{CCl}_{3} \mathrm{CO}_{2} \mathrm{H}$ proceeded with $\mathrm{HCl}$ release affording a mixture of $\mathrm{WCl}_{5}\left(\mathrm{O}_{2} \mathrm{CCCl}_{3}\right), \mathbf{3}$, and $\mathrm{WCl}_{4}\left(\mathrm{O}_{2} \mathrm{CCCl}_{3}\right)_{2}$, 4. Compound $\mathbf{3}$ was isolated from $\mathrm{WCl}_{6} / \mathrm{CCl}_{3} \mathrm{CO}_{2} \mathrm{H}$ (1:1 ratio) in $60 \%$ yield. All the metal products were characterized by analytical and spectroscopic techniques. The crystal structure of $\mathbf{1}$ was ascertained by X-ray diffractometry. DFT calculations were carried out in order to shed light into structural, mechanistic and thermodynamic features.
\end{abstract}

Keywords: Tungsten hexachloride, Carboxylic acids, Chlorination reactions, Carboxylato complexes, $\mathrm{X}$ ray structure, DFT calculations

\title{
1. Introduction
}

In the framework of our interest in the reactivity of high valent transition metal halides [1], we have been recently involved with some unexplored areas of the coordination chemistry of tungsten hexachloride [2]. A variety of reaction pathways may take place when $\mathrm{WCl}_{6}$ is allowed to contact with oxygen compounds, including $\mathrm{Cl} / \mathrm{O}$ interchange $[3,4]$ and $\mathrm{W}(\mathrm{VI})$ reduction to $\mathrm{W}(\mathrm{V})$ or $\mathrm{W}(\mathrm{IV})$ species [3a]. The capability of $\mathrm{WCl}_{6}$ of promoting chlorination of the carbonyl function has been clearly ascertained regarding aldehydes, ketones [3a] and $\alpha$-aminoacids [3b]; in this respect, the behavior of $\mathrm{WCl}_{6}$ resembles that of high-valent main group chlorides, e.g. $\mathrm{PCl}_{5}$ [5], which has been traditionally employed in organic chemistry as an effective chlorinating agent [6]. Metal 
reduction may be the most favorite route when $\mathrm{WCl}_{6}$ is allowed to contact with esters [3a,7]. Information concerning the direct interaction of $\mathrm{WCl}_{6}$ with carboxylic acids still remain rather sparse in the literature and, to the best of our knowledge, the reactivity of $\mathrm{WCl}_{6}$ with haloacetic acids has never been described hitherto. The dissolution of $\mathrm{WCl}_{6}$ in acetic acid was proposed as a convenient method for the preparation of mesoporous $\mathrm{W}_{18} \mathrm{O}_{49}$ photocatalyst [8]. Spectroscopic evidences indicated that $\mathrm{Cl} / \mathrm{O}$ interchange and $\mathrm{HCl}$ release occurred in the reactions of $\mathrm{WCl}_{6}$ with controlled amounts of $\mathrm{RCO}_{2} \mathrm{H}\left[\mathrm{R}=\mathrm{CH}_{3}, \mathrm{CH}_{2}=\mathrm{CH}\left(\mathrm{CH}_{2}\right)_{8}, \mathrm{CH}_{3}\left(\mathrm{CH}_{2}\right)_{10}\right]$, notwithstanding no metal products were isolated [9].

It deserves to be mentioned here that transition metal chlorides, including oxophilic chlorides of metals belonging to the groups 4 [10] and 5 [11], generally react with carboxylic acids affording carboxylato complexes via the release of $\mathrm{HCl}[12]$.

In the present paper, we report our study on the reactions of $\mathrm{WCl}_{6}$ with a selection of carboxylic acids, i.e. pyridine-3-carboxylic acid, acetic acid and halo- $\alpha$-substituted acetic acids. The reactions were carried out at room temperature in dichloromethane, i.e. a commonly considered scarcely coordinating solvent [13], under strictly anhydrous conditions. DFT calculations assisted the characterization of the products and the understanding of the different routes observed depending on the nature of the R substituent in $\mathrm{RCO}_{2} \mathrm{H}$.

\section{Results and Discussion}

The 1:1 molar reaction of pyridine-3-carboxylic acid with $\mathrm{WCl}_{6}$ led to the isolation of $\left[\mathrm{C}_{5} \mathrm{H}_{4} \mathrm{NHC}(\mathrm{O}) \mathrm{Cl}\right]\left[\mathrm{WOCl}_{5}\right], \mathbf{1}$, as a green solid in $75 \%$ yield (Scheme 1).

\section{Scheme 1 around here}

Compound 1 was characterized by elemental analysis, IR and NMR spectroscopy. X-ray quality crystals were obtained from a dichloromethane/hexane mixture: the X-ray structure of $\mathbf{1}$ is shown in Figure 1, whereas relevant bond lengths and angles are reported in Table 1. 


\section{Figure 1 and Table 1 around here}

The structure of the $\left[\mathrm{C}_{5} \mathrm{H}_{4} \mathrm{NHC}(\mathrm{O}) \mathrm{Cl}\right]^{+}$cation in $\mathbf{1}$ closely resembles that previously determined for the corresponding chloride salt [14]. An inter-molecular H-bond is present in $\mathbf{1}$ involving the pyridinium $\mathrm{N}(1)-\mathrm{H}(1)$ group of $\left[\mathrm{C}_{5} \mathrm{H}_{4} \mathrm{NHC}(\mathrm{O}) \mathrm{Cl}\right]^{+}$and the chloride ligand trans to the oxidogroup in $\left[\mathrm{WOCl}_{5}\right]^{-}$, i.e. $\mathrm{Cl}(5)$. The $\left[\mathrm{WOCl}_{5}\right]^{-}$anion displays a distorted octahedral geometry, as previously found [3b]. The $\mathrm{W}(1)-\mathrm{O}(1)$ distance [1.876(12) $\AA$ ] is indicative of a double bond [3a] and the oxido-ligand has a very strong trans influence. As a consequence, the $\mathrm{W}(1)-\mathrm{Cl}(5)$ distance $[2.535(5) \AA]$ is considerably longer than the other four $\mathrm{W}-\mathrm{Cl}$ distances $[2.304(5)-2.334(5) \AA]$.

The formation of $\mathbf{1}$ from the relevant carboxylic acid and $\mathrm{WCl}_{6}$ is the neat result of $\mathrm{Cl} / \mathrm{O}$ interchange between the organic reactant and the metal frame.

We moved to extend our investigation to the reactions of $\mathrm{WCl}_{6}$ with $\mathrm{CH}_{3} \mathrm{CO}_{2} \mathrm{H}, \mathrm{CCl}_{3} \mathrm{CO}_{2} \mathrm{H}$, $\mathrm{CBr}_{3} \mathrm{CO}_{2} \mathrm{H}$ and $\mathrm{CHCl}_{2} \mathrm{CO}_{2} \mathrm{H}$, respectively. In agreement with $\mathrm{NMR}$ and IR analyses, the 1:2 molar reaction of $\mathrm{WCl}_{6}$ with $\mathrm{CH}_{3} \mathrm{CO}_{2} \mathrm{H}$ smoothly proceeded to give $\mathrm{WOCl}_{4}\left(\mathrm{CH}_{3} \mathrm{CO}_{2} \mathrm{H}\right), 2, \mathrm{CH}_{3} \mathrm{C}(\mathrm{O}) \mathrm{Cl}$ and $\mathrm{HCl}$, as result of $\mathrm{Cl} / \mathrm{O}$ interchange between the $\mathrm{W}(\mathrm{VI})$ centre and acetic acid. 2 was isolated in the solid state, Eqn. 1.

$\mathrm{WCl}_{6}+2 \mathrm{CH}_{3} \mathrm{CO}_{2} \mathrm{H} \rightarrow \mathrm{WOCl}_{4}\left(\mathrm{CH}_{3} \mathrm{CO}_{2} \mathrm{H}\right)+\mathrm{CH}_{3} \mathrm{C}(\mathrm{O}) \mathrm{Cl}+\mathrm{HCl}$

2

The structure of 2 was optimized by DFT calculations (see Figure S1 and Table S1 within the Supporting Information). The lowest energy structure of $\mathbf{2}$ is shown in Figure 2, with the organic ligand occupying the trans position respect to the oxido moiety. The same configuration has been usually observed in $\mathrm{WOCl}_{4}(\mathrm{~L})$ complexes $(\mathrm{L}=\mathrm{O}$ donor) $[3 \mathrm{a}, 15]$. In $\mathbf{2}$, the coordination of acetic acid appears enforced by an intermolecular $\mathrm{H}---\mathrm{Cl}$ hydrogen bond interaction.

Figure 2 around here 
The IR spectrum of 2 (solid state) exhibited a diagnostic absorption at $1666 \mathrm{~cm}^{-1}$, attributed to the coordinated carbonyl group. The strong band observed at $1001 \mathrm{~cm}^{-1}$ accounts for the [W=O] moiety [3a, 9].

According to DFT outcomes, the $\mathrm{Cl} / \mathrm{O}$ interchange process leading to $\mathrm{WOCl}_{4}$ derivatives should be generally favored from $\mathrm{WCl}_{6}$ and $\mathrm{RCO}_{2} \mathrm{H}\left(\mathrm{R}=\mathrm{CCl}_{3}, \mathrm{CBr}_{3}, \mathrm{CHCl}_{2}\right)$, see Eqn. $2(\mathrm{M} 06$ functional, including $\mathrm{CH}_{2} \mathrm{Cl}_{2}$ implicit solvation).

\begin{tabular}{|c|c|c|}
\hline & $\mathrm{R}$ & $\Delta \mathrm{G}\left(\mathrm{kcal} \mathrm{\textrm {mol } ^ { - 1 } )}\right.$ \\
\hline & $\mathrm{CH}_{3}(\mathbf{2})$ & -27.6 \\
\hline & $\mathrm{CCl}_{3}$ & -7.5 \\
\hline & $\mathrm{CBr}_{3}$ & -15.6 \\
\hline & $\mathrm{CHCl}_{2}$ & -12.8 \\
\hline
\end{tabular}

It has to be noted that the reactions of $\mathrm{WOCl}_{4}$ with $\mathrm{RCO}_{2} \mathrm{H}$ and with $\mathrm{RC}(\mathrm{O}) \mathrm{Cl}\left(\mathrm{R}=\mathrm{CCl}_{3}, \mathrm{CBr}_{3}\right.$, $\mathrm{CHCl}_{2}$ ) proceeded sluggishly and afforded after work-up solid materials which were analyzed by IR spectroscopy (see Experimental). In general, the analyses revealed the presence of mixtures of products which could not be identified.

Surprisingly, the 1:2 molar reaction of $\mathrm{WCl}_{6}$ with $\mathrm{CCl}_{3} \mathrm{CO}_{2} \mathrm{H}$ was accompanied by $\mathrm{HCl}$ evolution but did fail to produce the expected $\mathrm{Cl} / \mathrm{O}$ interchange products (Eqn. 2). Combined IR [16] and NMR experiments and DFT analyses suggested the formation of the carboxylato complexes $\mathrm{WCl}_{5}\left[\mathrm{OC}(\mathrm{O}) \mathrm{CCl}_{3}\right], \mathbf{3}$, and $\mathrm{WCl}_{4}\left[\mathrm{OC}(\mathrm{O}) \mathrm{CCl}_{3}\right]_{2}, 4$. Reactions pathways involving reduction of the W(VI) centre should be excluded in the present case [17].

Calculated possible structures of $\mathbf{3}$ and $\mathbf{4}$ are shown in Figures S2 and S3. The most stable geometries consist of six-coordinated W(VI) centers to which one or two trichloroacetato groups, respectively in $\mathbf{3}$ and $\mathbf{4}$, behave as monodentate ligands (Figure 3). According to the DFT outcomes, the IR spectrum of the solid state mixture obtained from $\mathrm{WCl}_{6} / \mathrm{CCl}_{3} \mathrm{CO}_{2} \mathrm{H}$ (1:2 ratio) 
displayed three intense absorptions in the carbonyl region, i.e. at 1751 (3), 1709 (4) and 1669 (4) $\mathrm{cm}^{-1}$. No absorptions were found in the $[\mathrm{W}=\mathrm{O}]$ region $\left(990-1010 \mathrm{~cm}^{-1}\right)$.

\section{Figure 3 around here}

Calculations indicated that the introduction of the second carboxylato unit should not be considered as an easily viable process, Eqn. 3.

$$
\begin{gathered}
\mathrm{WCl}_{5}\left(\mathrm{O}_{2} \mathrm{CCCl}_{3}\right)+\mathrm{CCl}_{3} \mathrm{CO}_{2} \mathrm{H} \rightarrow \mathrm{WCl}_{4}\left(\mathrm{O}_{2} \mathrm{CCCl}_{3}\right)_{2}+\mathrm{HCl} \\
\Delta \mathrm{G}=+8.1 \mathrm{kcal} \mathrm{mol}^{-1}
\end{gathered}
$$

As a matter of fact, some unreacted $\mathrm{CCl}_{3} \mathrm{CO}_{2} \mathrm{H}$ was $\mathrm{NMR}$ detected in the reaction mixture $\mathrm{WCl}_{6} / \mathrm{CCl}_{3} \mathrm{CO}_{2} \mathrm{H}$ (1:2 molar ratio). Hence we could isolate 3 as a yellow solid by allowing $\mathrm{CCl}_{3} \mathrm{CO}_{2} \mathrm{H}$ to react with a slight excess of $\mathrm{WCl}_{6}$, Eqn. 4 .

$$
\mathrm{WCl}_{6}+\mathrm{CCl}_{3} \mathrm{CO}_{2} \mathrm{H} \rightarrow \mathrm{WCl}_{5}\left(\mathrm{O}_{2} \mathrm{CCCl}_{3}\right)+\mathrm{HCl}
$$

3

We carried out a DFT investigation in order to explain the different behaviors of $\mathrm{CH}_{3} \mathrm{CO}_{2} \mathrm{H}$ and $\mathrm{CCl}_{3} \mathrm{CO}_{2} \mathrm{H}$ when allowed to contact with $\mathrm{WCl}_{6}$. In both cases, the formation of mono-carboxylato complexes appears less favorable (Eqn. 5) compared to the $\mathrm{Cl} / \mathrm{O}$ interchange pathway (Eqn. 2).

$$
\begin{aligned}
& \mathrm{WCl}_{6}+\mathrm{RCO}_{2} \mathrm{H} \rightarrow \mathrm{WCl}_{5}\left(\mathrm{O}_{2} \mathrm{CR}\right)+\mathrm{HCl} \\
& \begin{array}{cc}
\hline \mathrm{R} & \Delta \mathrm{G}\left(\mathrm{kcal} \mathrm{mol}^{-1}\right) \\
\hline \mathrm{CH}_{3} & -1.4
\end{array} \\
& \mathrm{CCl}_{3}(\mathbf{3})+8.9
\end{aligned}
$$

A possible mechanism for the $\mathrm{Cl} / \mathrm{O}$ interchange reaction is shown in Figure 4 . The initial coordination of $\mathrm{RCO}_{2} \mathrm{H}$ to $\mathrm{WCl}_{6}$ should give the heptacoordinated complex $\mathrm{WCl}_{6}[\mathrm{O}=\mathrm{C}(\mathrm{OH}) \mathrm{R}]$. Clmigration may follow to form the hexacoordinated $\mathrm{WCl}_{5}[\mathrm{OC}(\mathrm{OH})(\mathrm{Cl}) \mathrm{R}]$. Subsequent $\mathrm{C}-\mathrm{O}$ bond 
breaking would result in the formation of $\mathrm{RC}(\mathrm{O}) \mathrm{Cl}, \mathrm{HCl}$ and $\mathrm{WOCl}_{4}$. The final product is the result of addition to $\mathrm{WOCl}_{4}$ of still unreacted $\mathrm{RCO}_{2} \mathrm{H}$. The structures of the calculated intermediate species in the course of the formation 2 are represented in Figures S4-S5 and as insets in Figure 4.

\section{Figure 4 around here}

Calculated $\Delta \mathrm{G}$ values (gas-phase EDF2 calculations) for Step B are quite similar irrespective of the nature of $\mathrm{R}\left(\mathrm{R}=\mathrm{CH}_{3}:-10.5 \mathrm{kcal} \mathrm{mol}^{-1} ; \mathrm{R}=\mathrm{CCl}_{3}:-12.5 \mathrm{kcal} \mathrm{mol}^{-1}\right)$. Even $\Delta \mathrm{G}^{\ddagger}$ values are closely comparable $\left(\mathrm{R}=\mathrm{CH}_{3}: 11.3 \mathrm{kcal} \mathrm{mol}^{-1} ; \mathrm{R}=\mathrm{CCl}_{3}\right.$ : $\left.9.7 \mathrm{kcal} \mathrm{mol}^{-1}\right)$. Similarly, the energy barrier for Step $\mathrm{C}$ should not be considered as discriminating $\left[\Delta \mathrm{G}^{\ddagger}\left(\mathrm{kcal} \mathrm{mol}{ }^{-1}\right): 6.4\left(\mathrm{R}=\mathrm{CH}_{3}\right)\right.$, $\left.10.6\left(\mathrm{R}=\mathrm{CCl}_{3}\right)\right]$. The crucial step seems to be the initial formation of the heptacoordinated complex (Step A, Figure 4). The corresponding calculated $\Delta H$ (gas-phase EDF2) is positive in both cases, but less unfavorable for $\mathrm{R}=\mathrm{CH}_{3}\left(8.6 \mathrm{kcal} \mathrm{mol}^{-1}\right)$ respect to $\mathrm{R}=\mathrm{CCl}_{3}(13.7 \mathrm{kcal}$ $\left.\mathrm{mol}^{-1}\right)$. Furthermore, EDF2 calculations provided very different $\mathrm{W}-\mathrm{O}$ bond lengths $(2.274 \AA$ for $\mathrm{R}$ $=\mathrm{CH}_{3}, 2.549 \AA$ for $\mathrm{R}=\mathrm{CCl}_{3}$ ). It is noteworthy that further geometry optimization of $\mathrm{WCl}_{6}[\mathrm{O}=\mathrm{C}(\mathrm{OH}) \mathrm{R}]$ in the presence of implicit solvation (M06/C-PCM calculations with $\mathrm{CH}_{2} \mathrm{Cl}_{2}$ as implicit solvent) provided a stable minimum only for $\mathrm{R}=\mathrm{CH}_{3}$; attempts to geometry optimization for $\mathrm{R}=\mathrm{CCl}_{3}$ led to $\mathrm{W}-\mathrm{O}$ breaking. The constrained coordination of trichloroacetic acid to $\mathrm{WCl}_{6}$ may be the reason for the non observed formation of the corresponding acylchloride species. Therefore alternative products, i.e. 3-4, could become accessible in spite of thermodynamic features (compare Eqns. 2 and 5). In principle, the synthesis of 3-4 might take place without preliminary coordination of the carboxylic acid to $\mathrm{WCl}_{6}$. Instead $\mathrm{Cl}_{5} \mathrm{WCl} \cdots \mathrm{HOC}(\mathrm{O}) \mathrm{CCl}_{3}$ interaction could be established, followed by release of $\mathrm{HCl}$ and formation of carboxylato units.

$\mathrm{WCl}_{6}$ was consumed by two molar equivalents of $\mathrm{CHCl}_{2} \mathrm{CO}_{2} \mathrm{H}$ in a few hours. The main metal product of this reaction, obtained in comparable amount respect to $\mathrm{CHCl}_{2} \mathrm{C}(\mathrm{O}) \mathrm{Cl}$, is proposed to be the complex $\mathrm{WOCl}_{3}\left(\mathrm{\kappa}^{2}-\mathrm{O}_{2} \mathrm{CCHCl}_{2}\right)$. Unfortunately, this product could not be purified, thus 
preventing its unambiguous characterization. The IR spectrum of the reaction residue displayed strong absorptions at 1611 and $1378 \mathrm{~cm}^{-1}$, ascribable to a bridging dichloroacetate ligand [18], and at $994 \mathrm{~cm}^{-1}(\mathrm{~W}=\mathrm{O})$. Minor absorption at $1663 \mathrm{~cm}^{-1}$ might be due to the presence of some WOCl${ }_{4}\left(\mathrm{CHCl}_{2} \mathrm{CO}_{2} \mathrm{H}\right)$; indeed the combination of $\mathrm{WOCl}_{4}$ with $\mathrm{CHCl}_{2} \mathrm{CO}_{2} \mathrm{H}$ afforded after workup a solid material whose IR analysis showed a major band at $1663 \mathrm{~cm}^{-1}$ (see Experimental).

The 1:2 molar reaction of $\mathrm{WCl}_{6}$ with $\mathrm{CBr}_{3} \mathrm{CO}_{2} \mathrm{H}$ produced $\mathrm{HCl}$ and afforded a mixture of products. Non coordinated $\mathrm{CBr}_{3} \mathrm{COCl}$ was clearly identified in the mixture $[19,20]$. Accordingly, the IR spectrum [21] of the solid residue obtained from the reaction displayed a strong band at $1002 \mathrm{~cm}^{-1}$, ascribable to tungsten oxido species. On the other hand, bands were detected at 1768 , 1733, 1689, presumably accounting for carboxylato complexes analogous to $\mathbf{3}$ and $\mathbf{4}$ (see Figures S6 and S7). These evidences suggest that two distinct pathways are feasible in the course of the interaction $\mathrm{WCl}_{6}-\mathrm{CBr}_{3} \mathrm{CO}_{2} \mathrm{H}$, i.e. $\mathrm{Cl} / \mathrm{O}$ interchange and formation of carboxylato species. The major product of the $\mathrm{WCl}_{6} / \mathrm{CBr}_{3} \mathrm{CO}_{2} \mathrm{H}$ interaction displays IR bands at 1584 and $1355 \mathrm{~cm}^{-1}$, possibly related to a bidentate chelating tribromocarboxylato ligand [22].

\section{Conclusions}

The reactions of $\mathrm{WCl}_{6}$ with limited amounts of a series of carboxylic acids have been elucidated by means of spectroscopic and DFT studies. Both $\mathrm{Cl} / \mathrm{O}$ interchange process and formation of carboxylato moieties are viable routes which may take place either selectively or not, depending on the nature of the employed carboxylic acid. DFT calculations have suggested that $\mathrm{Cl} / \mathrm{O}$ interchange, via the initial formation of a heptacoordinated adduct, should be considered as the favorite outcome, nevertheless it may be kinetically inhibited on going from $\mathrm{CH}_{3} \mathrm{CO}_{2} \mathrm{H}$ to its $\alpha$ halo-substituted derivatives.

\section{Experimental}


4.1. General considerations. Air/moisture sensitive compounds were manipulated under atmosphere of pre-purified nitrogen using standard Schlenk techniques. The reaction vessels were oven dried at $150{ }^{\circ} \mathrm{C}$ prior to use, evacuated $\left(10^{-2} \mathrm{mmHg}\right)$ and then filled with argon. $\mathrm{WCl}_{6}$ (99.9\%, Strem), $\mathrm{PCl}_{5}(98+\%$, Apollo Sci.) and organic reactants (Sigma-Aldrich) were stored under argon as received. $\mathrm{WOCl}_{4}$ was prepared according to the literature [23]. Once isolated, the metal products were conserved in sealed glass tubes under argon. Solvents (Sigma-Aldrich) were distilled before use from $\mathrm{CaH}_{2}$. Infrared spectra were recorded at $298 \mathrm{~K}$ on a FT IR-Perkin Elmer Spectrometer, equipped with UATR sampling accessory. NMR spectra were recorded on a Bruker Avance 2 DRX400 instrument equipped with BBFO broadband probe, at $298 \mathrm{~K}$. The chemical shifts for ${ }^{1} \mathrm{H}$ and ${ }^{13} \mathrm{C}$ were referenced to the non-deuterated aliquot of the solvent. Carbon, hydrogen and nitrogen analyses were performed on Carlo Erba mod. 1106 instrument. The halogen content was determined by the Mohr method [24] on solutions prepared by prolonged dissolution of the solid in aqueous $\mathrm{KOH}$ at boiling temperature, followed by cooling to room temperature and addition of $\mathrm{HNO}_{3}$ up to neutralization.

4.2. Synthesis and isolation of $\left[\mathrm{C}_{5} \mathrm{H}_{4} \mathrm{NH}(\mathrm{CO}) \mathrm{Cl}\right]\left[\mathrm{WOCl}_{5}\right]$, 1. A mixture of $\mathrm{WCl}_{6}(0.350 \mathrm{~g}, 0.882$ mmol), pyridine-3-carboxylic acid $(0.110 \mathrm{~g}, 0.894 \mathrm{mmol})$ and $\mathrm{CH}_{2} \mathrm{Cl}_{2}(15 \mathrm{~mL})$ was allowed to stir at room temperature for $48 \mathrm{~h}$. Then the abundant green precipitate, corresponding to $\mathbf{1}$, was separated from the solution and dried in vacuo. Yield $0.343 \mathrm{~g}, 75 \%$. The solution was layered with hexane and settled aside at $-30{ }^{\circ} \mathrm{C}$ : few crystals suitable for X-ray analysis were collected after 72 h. Anal. Calcd. for $\mathrm{C}_{6} \mathrm{H}_{5} \mathrm{Cl}_{6} \mathrm{NO}_{2} \mathrm{~W}$ : C, 13.87; H, 0.97; N, 2.70; Cl, 40.93. Found: C, 13.61; H, 0.84; N, 2.66; Cl, 40.81. IR (solid state): $v=3173 \mathrm{w}, 3071 \mathrm{~m}-\mathrm{br}, 2867 \mathrm{w}-\mathrm{br}, 1808 \mathrm{~s}(\mathrm{C}=\mathrm{O}), 1728 \mathrm{~m}-$ br, 1633m, 1603m, 1543m, 1463s, 1409w-m, 1348w, 1293w, 1262m, 1217s, $1107 \mathrm{w}, 1053 \mathrm{~s}$, $1037 \mathrm{~m}-\mathrm{sh}, 1015 \mathrm{~s}, 981 \mathrm{~m}, 895 \mathrm{~m}, 775 \mathrm{~s}, 715 \mathrm{vs}, 695 \mathrm{~s}, 664 \mathrm{vs} \mathrm{cm}{ }^{-1} \cdot{ }^{1} \mathrm{H} \mathrm{NMR}\left(\mathrm{CD}_{3} \mathrm{CN}\right) \delta=12.7$ (br, 
1H, NH); 9.46-8.90, 8.35-8.21 ppm (arom CH). ${ }^{13} \mathrm{C}\left\{{ }^{1} \mathrm{H}\right\}$ NMR $\left(\mathrm{CD}_{3} \mathrm{CN}\right) \delta=162.7(\mathrm{C}=\mathrm{O}) ; 148.2$, $145.2,143.1,128.7 \mathrm{ppm}($ arom).

4.3. Reactions of $\mathrm{WCl}_{6}$ with $\mathrm{RCO}_{2} \mathrm{H}\left(\mathrm{R}=\mathrm{CH}_{3}, \mathrm{CHCl}_{2}, \mathrm{CCl}_{3}, \mathrm{CBr}_{3}\right)$ in 1:2 molar ratios. Identification of $\mathrm{RC}(\mathrm{O}) \mathrm{Cl}\left(\mathrm{R}=\mathrm{CH}_{3}, \mathrm{CHCl}_{2}, \mathrm{CBr}_{3}\right), \mathrm{WCl}_{4}\left(\mathrm{O}_{2} \mathrm{CCCl}_{3}\right)_{2}, 4$, and isolation of $\mathrm{WOCl}_{4}\left(\mathrm{CH}_{3} \mathrm{CO}_{2} \mathrm{H}\right), 2$, and $\mathrm{WCl}_{5}\left(\mathrm{O}_{2} \mathrm{CCCl}_{3}\right), 3$.

A) NMR analyses. $\mathrm{WCl}_{6}(0.35 \mathrm{mmol}), \mathrm{CD}_{2} \mathrm{Cl}_{2}(1.5 \mathrm{~mL})$, and the appropriate carboxylic acid $(0.70$ mmol) were introduced into a Schlenk tube in the order given. The mixture was stirred at room temperature for a variable time. During this period, the system was purged with argon in order to remove the released gas $(\mathrm{HCl})$. Bubbling the latter into an aqueous solution of $\mathrm{AgNO}_{3}$ determined the precipitation of a white solid $(\mathrm{AgCl})$. An aliquot of the final mixture was transferred into a NMR tube and then analyzed by NMR spectroscopy.

1) From $\mathrm{WCl}_{6} / \mathrm{CH}_{3} \mathrm{CO}_{2} \mathrm{H}$. Yellow solution, reaction time 4 h. ${ }^{1} \mathrm{H} \mathrm{NMR}\left(\mathrm{CD}_{2} \mathrm{Cl}_{2}\right) \delta=9.24(\mathrm{~s}, \mathrm{OH}$, 2); $2.69\left(\mathrm{~s}, \mathrm{CH}_{3}, \mathrm{CH}_{3} \mathrm{COCl}\right), 2.50 \mathrm{ppm}\left(\mathrm{s}, \mathrm{CH}_{3}, 2\right)$. Ratio $\mathrm{CH}_{3} \mathrm{COCl} / 2=$ ca. 1:1.2. ${ }^{13} \mathrm{C}\left\{{ }^{1} \mathrm{H}\right\} \mathrm{NMR}$ $\left(\mathrm{CD}_{2} \mathrm{Cl}_{2}\right) \delta=181.9(\mathrm{CO}, 2) ; 171.2\left(\mathrm{CO}, \mathrm{CH}_{3} \mathrm{C}(\mathrm{O}) \mathrm{Cl}\right) ; 33.9\left(\mathrm{CH}_{3}, \mathrm{CH}_{3} \mathrm{C}(\mathrm{O}) \mathrm{Cl}\right) ; 21.5$ ppm $\left(\mathrm{CH}_{3}\right.$, 2).

2) From $\mathrm{WCl}_{6} / \mathrm{CCl}_{3} \mathrm{CO}_{2} \mathrm{H}$. Yellow solution over yellow precipitate, reaction time $96 \mathrm{~h} .{ }^{1} \mathrm{H}$ NMR $\left(\mathrm{CD}_{2} \mathrm{Cl}_{2}\right) \delta=10.2$ ppm (br, OH, $\left.\mathrm{CCl}_{3} \mathrm{CO}_{2} \mathrm{H}\right) \cdot{ }^{13} \mathrm{C}\left\{{ }^{1} \mathrm{H}\right\}$ NMR $\left(\mathrm{CD}_{2} \mathrm{Cl}_{2}\right) \delta=166.1(\mathrm{CO}$ $\left.\mathrm{CCl}_{3} \mathrm{CO}_{2} \mathrm{H}\right) ; 163.7,160.0(\mathrm{CO}) ; 88.7\left(\mathrm{CCl}_{3}, \mathrm{CCl}_{3} \mathrm{CO}_{2} \mathrm{H}\right), 88.6,86.9 \mathrm{ppm}\left(\mathrm{CCl}_{3}\right)$.

3) From $\mathrm{WCl}_{6} / \mathrm{CBr}_{3} \mathrm{CO}_{2} \mathrm{H}$. Red solution, reaction time 18 h. ${ }^{13} \mathrm{C}\left\{{ }^{1} \mathrm{H}\right\} \mathrm{NMR}\left(\mathrm{CD}_{2} \mathrm{Cl}_{2}\right) \delta=169.7$, 169.5, 167.3, $160.3(\mathrm{CO}) ; 162.9\left(\mathrm{CO}, \mathrm{CBr}_{3} \mathrm{C}(\mathrm{O}) \mathrm{Cl}\right) ; 34.6\left(\mathrm{CBr}_{3}, \mathrm{CBr}_{3} \mathrm{C}(\mathrm{O}) \mathrm{Cl}\right) ; 31.9,30.4,26.7$ $\operatorname{ppm}\left(\mathrm{CBr}_{3}\right)$. 
4) From $\mathrm{WCl}_{6} / \mathrm{CHCl}_{2} \mathrm{CO}_{2} \mathrm{H}$. Yellow solution, reaction time 4 h. ${ }^{1} \mathrm{H} \mathrm{NMR}\left(\mathrm{CD}_{2} \mathrm{Cl}_{2}\right) \delta=6.25(\mathrm{~s}$, $\left.\mathrm{CH}, \mathrm{CHCl}_{2} \mathrm{C}(\mathrm{O}) \mathrm{Cl}\right), 6.21 \mathrm{ppm}(\mathrm{s}, \mathrm{CH}), \mathrm{OH}$ not observed. ${ }^{13} \mathrm{C}\left\{{ }^{1} \mathrm{H}\right\}$ NMR $\left(\mathrm{CD}_{2} \mathrm{Cl}_{2}\right) \delta=169.6$ (CO); $165.7\left(\mathrm{CO}, \mathrm{CHCl}_{2} \mathrm{C}(\mathrm{O}) \mathrm{Cl}\right) ; 70.3\left(\mathrm{CH}, \mathrm{CHCl}_{2} \mathrm{C}(\mathrm{O}) \mathrm{Cl}\right) ; 63.6 \mathrm{ppm}(\mathrm{CH})$.

B) Solid state IR analyses.

IR analyses were performed on solid residues which were obtained with a procedure similar to that described for the preparation of the NMR samples, by allowing $\mathrm{WCl}_{6}(0.70 \mathrm{mmol})$ to react with the appropriate carboxylic acid $(1.4 \mathrm{mmol})$ in $\mathrm{CH}_{2} \mathrm{Cl}_{2}$ (ca. $\left.10 \mathrm{~mL}\right)$. The final mixture was dried in vacuo thus affording the residue for IR analysis.

1) From $\mathrm{WCl}_{6} / \mathrm{CH}_{3} \mathrm{CO}_{2} \mathrm{H}$. Yellow oily solid. IR (solid state): $v=1666 \mathrm{~s}(\mathrm{C}=\mathrm{O}, 2), 1627 \mathrm{~m}, 1001 \mathrm{vs}$ $(\mathrm{W}=\mathrm{O}) \mathrm{cm}^{-1}$.

2) From $\mathrm{WCl}_{6} / \mathrm{CCl}_{3} \mathrm{CO}_{2} \mathrm{H}$. Yellow solid. IR (solid state): $v=1751 \mathrm{~s}(\mathrm{C}=\mathrm{O}, \mathbf{3}), 1709 \mathrm{vs}-\mathrm{br}(\mathrm{C}=\mathrm{O}, \mathbf{4})$, $1669 \mathrm{~m}(\mathrm{C}=\mathrm{O}, 4), 1637 \mathrm{w}, 1621 \mathrm{w}, 1602 \mathrm{w}, 1087 \mathrm{~s}-\mathrm{br}(\mathrm{C}-\mathrm{O}) \mathrm{cm}^{-1}$.

3) From $\mathrm{WCl}_{6} / \mathrm{CBr}_{3} \mathrm{CO}_{2} \mathrm{H}$. Orange sticky solid. IR (solid state): $v=1825 \mathrm{~m}, 1768 \mathrm{w}, 1733 \mathrm{~m}$, $1724 \mathrm{~m}-\mathrm{sh}, 1689 \mathrm{~m}, 1675 \mathrm{w}-\mathrm{m}, 1584 \mathrm{~s}, 1385 \mathrm{~s}, 1002 \mathrm{vs} \mathrm{cm}^{-1}$.

4) From $\mathrm{WCl}_{6} / \mathrm{CHCl}_{2} \mathrm{CO}_{2} \mathrm{H}$. Yellow sticky solid. IR (solid state): $v=1663 \mathrm{w}, 1611 \mathrm{vs,} 1378 \mathrm{vs}$, $994 \mathrm{vs} \mathrm{cm}^{-1}$.

\section{C) Isolation of $\mathbf{2}$ and 3 .}

A suspension of $\mathrm{WCl}_{6}(0.410 \mathrm{~g}, 1.03 \mathrm{mmol})$ in $\mathrm{CH}_{2} \mathrm{Cl}_{2}(15 \mathrm{~mL})$ was treated with $\mathrm{CH}_{3} \mathrm{CO}_{2} \mathrm{H}(0.12$ $\mathrm{mL}, 2.10 \mathrm{mmol}$ ). The mixture was stirred at room temperature for $18 \mathrm{~h}$. The final mixture was added of hexane $(40 \mathrm{~mL})$, thus affording a precipitate which was isolated and dried in vacuo. A similar procedure led to the isolation of 3 , from $\mathrm{WCl}_{6}(0.320 \mathrm{~g}, 0.806 \mathrm{mmol})$ and $\mathrm{CCl}_{3} \mathrm{CO}_{2} \mathrm{H}$ (0.130 g, $0.796 \mathrm{mmol})$.

2. Yellow solid, yield $0.170 \mathrm{~g}(41 \%)$. Anal. Calcd. for $\mathrm{C}_{2} \mathrm{H}_{4} \mathrm{Cl}_{4} \mathrm{O}_{3} \mathrm{~W}: \mathrm{C}, 5.98 ; \mathrm{H}, 1.00 ; \mathrm{Cl}, 35.30$. Found: C, 6.03; H, 0.96; Cl, 35.12. IR (solid state): $v=1665 \mathrm{vs}(\mathrm{C}=\mathrm{O}), 1001 \mathrm{vs}(\mathrm{W}=\mathrm{O}) \mathrm{cm}^{-1} .{ }^{1} \mathrm{H}$ 
$\operatorname{NMR}\left(\mathrm{CD}_{2} \mathrm{Cl}_{2}\right) \delta=9.27(\mathrm{~s}, 1 \mathrm{H}, \mathrm{OH}) ; 2.53 \mathrm{ppm}\left(\mathrm{s}, 3 \mathrm{H}, \mathrm{CH}_{3}\right) .{ }^{13} \mathrm{C}\left\{{ }^{1} \mathrm{H}\right\} \mathrm{NMR}\left(\mathrm{CD}_{2} \mathrm{Cl}_{2}\right) \delta=181.6$ (CO); $21.5 \mathrm{ppm}\left(\mathrm{CH}_{3}\right)$.

3. Yellow solid, yield $0.250 \mathrm{~g}(60 \%)$. Anal. Calcd. for $\mathrm{C}_{2} \mathrm{Cl}_{8} \mathrm{O}_{2} \mathrm{~W}: \mathrm{C}, 4.59 ; \mathrm{H}, 0.00 ; \mathrm{Cl}, 54.18$. Found: C, 4.66; H, 0.03; $\mathrm{Cl}, 53.97$. IR (solid state) $: \mathrm{v}=1751 \mathrm{vs}(\mathrm{C}=\mathrm{O}) \mathrm{cm}^{-1}$.

4.4. Reactions of $\mathrm{WOCl}_{4}$ with $\mathrm{RCO}_{2} \mathrm{H}\left(\mathrm{R}=\mathrm{CHCl}_{2}, \mathrm{CCl}_{3}, \mathrm{CBr}_{3}\right)$ in 1:1 molar ratio. Solid state IR analyses.

IR analyses were performed on solid residues obtained with a procedure similar to that described for $\mathrm{WCl}_{6} / \mathrm{RCO}_{2} \mathrm{H}$, by allowing $\mathrm{WOCl}_{4}(0.70 \mathrm{mmol})$ to react with the appropriate carboxylic acid $(0.70 \mathrm{mmol})$ in $\mathrm{CH}_{2} \mathrm{Cl}_{2}$ (ca. $10 \mathrm{~mL}$ ). The final mixture was dried in vacuo thus affording the residue for IR analysis.

1) From $\mathrm{WOCl}_{4} / \mathrm{CCl}_{3} \mathrm{CO}_{2} \mathrm{H}$. Light orange solid. IR (solid state): $v=1719 \mathrm{vs}, 1590 \mathrm{w}-\mathrm{m} \mathrm{cm}{ }^{-1}$.

2) From $\mathrm{WOCl}_{4} / \mathrm{CBr}_{3} \mathrm{CO}_{2} \mathrm{H}$. Yellow-red solid. IR (solid state): $v=1721 \mathrm{~s}, 1618 \mathrm{~m}-\mathrm{sh}, 1584 \mathrm{~s}$, $1355 \mathrm{~s}, 1002 \mathrm{~s} \mathrm{~cm}^{-1}$.

3) From $\mathrm{WOCl}_{4} / \mathrm{CHCl}_{2} \mathrm{CO}_{2} \mathrm{H}$. Yellow-brown solid. IR (solid state): $v=1738 \mathrm{w}, 1701 \mathrm{w}, 1663 \mathrm{~s}$, $1622 \mathrm{~m}, 1010 \mathrm{~s}-\mathrm{br} \mathrm{cm}{ }^{-1}$.

4.5. Reactions of $\mathrm{WOCl}_{4}$ with $\mathrm{RC}(\mathrm{O}) \mathrm{Cl}\left(\mathrm{R}=\mathrm{CHCl}_{2}, \mathrm{CCl}_{3}, \mathrm{CBr}_{3}\right)$ in 1:1 molar ratio. Solid state IR analyses.

General procedure: A suspension of $\mathrm{PCl}_{5}$ in $\mathrm{CH}_{2} \mathrm{Cl}_{2}(15 \mathrm{~mL})$ was treated with $\mathrm{RCO}_{2} \mathrm{H}$. A colorless solution formed in one hour. Then $\mathrm{WOCl}_{4}$ was added to the solution, and the resulting mixture was stirred for $18 \mathrm{~h}$ at room temperature. Hence hexane $(20 \mathrm{~mL})$ was added, and the obtained precipitate was isolated and dried in vacuo.

1) From $\mathrm{WOCl}_{4} / \mathrm{CCl}_{3} \mathrm{CO}_{2} \mathrm{H}$. Green solid. IR (solid state): $v=1753 \mathrm{w}, 1606 \mathrm{~m}-\mathrm{br}, 1006 \mathrm{~m} \mathrm{~cm}^{-1}$. 
2) From $\mathrm{WOCl}_{4} / \mathrm{CBr}_{3} \mathrm{CO}_{2} \mathrm{H}$. Light green solid. IR (solid state): $v=1774 \mathrm{vs}, 1003 \mathrm{~s} \mathrm{~cm}^{-1}$.

3) From $\mathrm{WOCl}_{4} / \mathrm{CHCl}_{2} \mathrm{CO}_{2} \mathrm{H}$. Light brown solid. IR (solid state): $v=1586 \mathrm{~m}, 1003 \mathrm{~s} \mathrm{~cm}^{-1}$.

4.6. X-ray crystallographic study. Crystal data and collection details for $\mathbf{1}$ are reported in Table 2. The diffraction experiment was carried out on a Bruker APEX II diffractometer equipped with a CCD detector and using Mo-K $\alpha$ radiation $(\lambda=0.71073 \AA)$. Data were corrected for Lorentz polarization and absorption effects (empirical absorption correction SADABS) [25]. The structure was solved by direct method and refined by full-matrix least-squares based on all data using $F^{2}$ [26]. All non-hydrogen atoms were refined with anisotropic displacement parameters. H-atoms were placed in calculated positions and treated isotropically using the 1.2 fold $U_{\text {iso }}$ value of the parent atom. The N-bonded hydrogen atom H(1) was initially located in the Fourier map but, then, it was refined with a riding model. Similar $U$ restraints were applied to the $\left[\mathrm{C}_{5} \mathrm{H}_{4} \mathrm{NHC}(\mathrm{O}) \mathrm{Cl}\right]^{+}$ cation [SIMU line in SHELXL; s.u. 0.02].

\section{Table 2 around here}

4.7. Computational studies. The computational geometry optimization of the complexes was carried out without symmetry constrains using the hyper-GGA functional M06 [27] in combination with the 6-31G(d,p) basis sets on $\mathrm{H}, \mathrm{C}, \mathrm{O}$ and $\mathrm{Cl}$ atoms and the ECP-based polarized basis sets LANL2DZ(p) on Br [28] and LANL2TZ(f) on W [29]. C-PCM implicit solvation model for dichloromethane was added to M06 calculations [30]. Ground- and transition-state optimizations were also performed using the hybrid DFT functional EDF2 [31] in combination with the LACVP** basis set [32]. In all of the cases the stationary points were characterized by IR simulations, from which zero-point vibrational energies and thermal corrections were obtained. DFT-simulated IR data, obtained with harmonic approximation, assisted the interpretation of experimental IR spectra [33]. The software used were Gaussian 09 [34] and Spartan 08 [35]. 
Appendix A. Supplementary data. Figures S1-S7 show the DFT-calculated structures discussed in this paper. Tables S1-S7 contain the relevant computed bonding parameters. Cartesian coordinates of the optimized geometries are collected in a separated .xyz file. CCDC 1401458 contains the supplementary crystallographic data for $\mathbf{1}$. These data can be obtained free of charge via www.ccdc.cam.ac.uk/conts/retrieving.html or from the Cambridge Crystallographic Data Centre, 12 Union Road, CambridgeCB2 1EZ, UK; fax: (+44)-1223-336-033; e-mail: deposit@ccdc.cam.ac.uk.

Acknowledgements. University of Pisa is gratefully acknowledged for financial support.

\section{References}

1 See for instance:

a) M. Bortoluzzi, E. Ferretti, F. Marchetti, G. Pampaloni, S. Zacchini, Chem. Commun. 50 (2014) 4472-4474.

b) F. Marchetti, G. Pampaloni C. Pinzino, Chem. Eur. J. 19 (2013) 13962-13969.

c) T. Funaioli, F. Marchetti, G. Pampaloni, S. Zacchini, Dalton Trans. 42 (2013) 1416814177.

d) F. Marchetti, G. Pampaloni, Chem. Commun. 48 (2012) 635-653.

2 a) M. Bortoluzzi, F. Marchetti, G. Pampaloni, S. Zacchini, Chem. Commun. 51 (2015) 13231325.

b) M. Bortoluzzi, F. Marchetti, G. Pampaloni, S. Zacchini, Inorg. Chem. 53 (2014) 38323838.

c) S. Dolci, F. Marchetti, G. Pampaloni, S. Zacchini, Dalton Trans. 39 (2010) 5367-5376.

3 a) S. Dolci, F. Marchetti, G. Pampaloni, S. Zacchini, Dalton Trans. 42 (2013) 5635-5648. 
b) M. Bortoluzzi, F. Marchetti, M. G. Murrali, G. Pampaloni, S. Zacchini, Dalton Trans. 44 (2015) 8729-8738.

4 P. D. W. Boyd, M. G. Glenny, C. E.F. Rickard, A. J. Nielson, Polyhedron 30 (2011) 632-637.

5 a) M. Bortoluzzi, F. Marchetti, M. G. Murrali, G. Pampaloni, Inorg. Chim. Acta 427 (2015) 150-154.

b) A. L. Fuentes de Arriba, L. Simón, C. Raposo, V. Alcázar, J. R. Morán, Tetrahedron 65 (2009) 4841-4845.

c) E. V. Dehmlow, H. G. Schell, Chem. Ber. 113 (1980) 1-8.

d) K. Griesbaum, A. R. Bandyopadhyay, M. Meister, Can. J. Chem. 64 (1986) 1553-1559.

6 J. E. Burks Jr., Encyclopedia of Reagents for Organic Synthesis: Phosphorus(V) Chloride, Eli Lilly, Company, Lafayette, IN, USA (2001).

7 H. Balcar, A. Dosedlova, B. Matyska, Coll. Czech. Chem. Commun. 51 (1986) 753-762.

8 Z.-F. Huang, J. Song, L. Pan, F. Lv, Q. Wang, J.-J. Zou, X. Zhang, Li Wang, Chem. Commun. 50 (2014) 10959-10962.

9 H. Balcar, A. Dosedlova, B. Matyska, J. Mol. Catal. 41 (1987) 367-374.

10 a) T. J. Boyle, D. T. Yonemoto, T. Q. Doan, T. M. Alam, Inorg. Chem. 53 (2014) 1244912458.

b) J. Amaudrut, B. Viard, R. Mercier, J. Chem. Res., Synopses (1979) 138-139.

c) D. Schwartz, P. Reski, J. Inorg. Nucl. Chem. 32 (1970) 1045-1046.

d) K. H. Gayer, S. F. Pavkovic, G. J. Tennenhouse, Z. Anorg. Allg. Chem. 354 (1967) 74-77.

e) R. N. Kapoor, K. C. Pande, R. C. Mehrotra, J. Ind. Chem. Soc. 35 (1958) 157-159.

11 a) F. Marchetti, G. Pampaloni, S. Zacchini, Polyhedron 27 (2008) 1969-1976.

b) D. A. Brown, W. Errington, M. G. H. Wallbridge, J. Chem. Soc. Dalton Trans. (1993) 1163-1164. 

c) D. M. Halepoto, L. F. Larkworthy, D. C. Povey, G. W. Smith, V. Ramdas, Polyhedron 14 (1995) 1453-1460.

d) R. Kapoor, R. Sharma, P. Kapoor, Ind. J. Chem. 24A (1985) 761-764.

e) B. Viard, A. Laarif, F. Theobald, J. Amadrut, J. Chem. Res. Synopses (1983) 252-253.

f) H. J. Seifert, J. Inorg. Nucl. Chem. 27 (1965) 1269-1270.

12 a) R. C. Merhotra, R. Bohra, Metal Carboxylates, Academic Press, New York (1983).

b) C. Oldham, Progr. Inorg. Chem. 10 (1968) 223-258.

13 A. Decken, C. Knapp, G. B. Nikiforov, J. Passmore, J. M. Rautiainen, X. Wang, X. Zeng, Chem. Eur. J. 5 (2009) 6504-6517.

14 K. I. Nattinen, K. Rissanen, Cryst. Eng. Comm. 5 (2003) 326-330.

15 L. W. Bassi, R. Scordamaglia, J. Organomet. Chem. 99 (1975) 127-134.

16 IR spectrum of commercial $\mathrm{CCl}_{3} \mathrm{CO}_{2} \mathrm{H}: v=1738 \mathrm{vs}(\mathrm{C}=\mathrm{O}) \mathrm{cm}^{-1}$.

17 Calculated $\Delta \mathrm{H}$ for the reaction $\mathrm{WCl}_{6}+\mathrm{CCl}_{3} \mathrm{CO}_{2} \mathrm{H} \rightarrow \mathrm{WCl}_{5}\left(\mathrm{CCl}_{3} \mathrm{CO}_{2} \mathrm{H}\right)+1 / 2 \mathrm{Cl}_{2}$ resulted +77 kcal $\mathrm{mol}^{-1}$.

18 F. Pavelčík, B. M. Žemlička, A. V. Kettmann, A. J. Krätsmar-Šmogrovič, Chem. Papers 41 (1987) 433-440.

19 A solution of $\mathrm{CBr}_{3} \mathrm{CO}_{2} \mathrm{H}(0.180 \mathrm{~g}, 0.607 \mathrm{mmol})$ in $\mathrm{CDCl}_{3}(0.7 \mathrm{~mL})$ was treated with $\mathrm{PCl}_{5}$ (0.128 g, $0.615 \mathrm{mmol})$. The resulting colorless solution was analyzed by NMR. ${ }^{13} \mathrm{C}\left\{{ }^{1} \mathrm{H}\right\}$ $\operatorname{NMR}\left(\mathrm{CDCl}_{3}\right) \delta=162.6(\mathrm{C}=\mathrm{O}) ; 34.7 \mathrm{ppm}\left(\mathrm{CBr}_{3}\right) .{ }^{31} \mathrm{P} \mathrm{NMR}\left(\mathrm{CDCl}_{3}\right) \delta=4.2 \mathrm{ppm}\left[\mathrm{P}(\mathrm{O}) \mathrm{Cl}_{3}\right]$.

20 M. Bortoluzzi, F. Marchetti, G. Pampaloni, S. Zacchini, Dalton Trans. 43 (2014) 1641616423.

21 IR spectrum of commercial $\mathrm{CBr}_{3} \mathrm{CO}_{2} \mathrm{H}: \mathrm{v}=1715 \mathrm{vs}(\mathrm{C}=\mathrm{O}) \mathrm{cm}^{-1}$.

22 J. K. Puri, A. Miglani, M. Malhotra, V. K. Sharma, Inorg. Chim. Acta 170 (1990) 103-107.

23 V. C. Gibson, T. P. Kee, A. Shaw, A. Polyhedron 9, (1990) 2293-2298. 
24 D. A. Skoog, D. M. West, Fundamentals of Analytical Chemistry, 2nd Edition, Holt, Rinehart, Winston, Chatham, UK (1974) 233.

25 G. M. Sheldrick, SADABS, Program for empirical absorption correction, University of Göttingen, Göttingen, Germany (1996).

26 G. M. Sheldrick, SHELX97, University of Göttingen, Göttingen, Germany (1997).

27 Y. Zhao, D. G. Truhlar, Theor. Chem. Acc. 120 (2008) 215-241.

28 C. E. Check, T. O. Faust, J. M. Bailey, B. J. Wright, T. M. Gilbert, L. S. Sunderlin, J. Phys. Chem. A 105 (2001) 8111-8116.

29 L. E. Roy, P. J. Hay, R. L. Martin, J. Chem. Theory Comput. 4 (2008) 1029-1031.

30 a) V. Barone, M. Cossi, J. Phys. Chem. A 102 (1998) 1995-2001.

b) M. Cossi, N. Rega, G. Scalmani, V. Barone, J. Comput. Chem. 24 (2003) 669-681

31 C. Y. Lin, M. W. George, P. M. W. Gill, Aust. J. Chem. 57 (2004) 365-370.

32 a) W. J Henre, R. Ditchfield, J. A. Pople, J. Chem. Phys. 56 (1972) 2257-2261.

b) P. J. Hay, W. R. Wadt, J. Chem. Phys. 82 (1985) 270-283.

c) P. J. Hay, W. R. Wadt, J. Chem. Phys. 82 (1985) 299-310.

d) M. Dolg, Modern Methods and Algorithms of Quantum Chemistry, J. Grotendorst (Ed.), John Neumann Institute for Computing, NIC series, Jülich 1 (2000) 479-508.

33 a) C. J. Cramer, Essentials of Computational Chemistry, 2nd Ed., Wiley, Chichester (2004).

b) F. Jensen, Introduction to Computational Chemistry, 2nd Ed., Wiley, Chichester (2007).

34 Gaussian 09, Revision C.01, M. J. Frischetal.; Gaussian, Inc., Wallingford CT (2010).

35 Spartan '08, version 1.1.1, Wavefunction, Inc., Irvine CA (2009). Except for molecular mechanics and semi-empirical models, the calculation methods used in Spartan have been documented in: Y. Shao, et al., Phys. Chem. Chem. Phys. 8 (2006) 3172. 


\section{SCHEME 1}

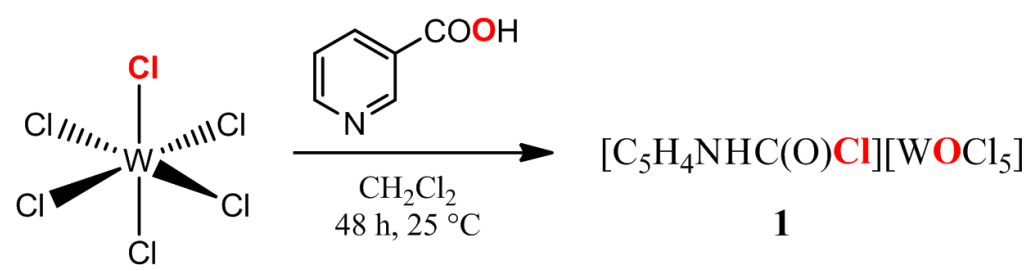

Scheme 1. $\mathrm{Cl} / \mathrm{O}$ interchange between $\mathrm{WCl}_{6}$ and pyridine-3-carboxylic acid. 


\section{Captions for Figures and Tables}

Figure 1. Molecular structure of $\left[\mathrm{C}_{5} \mathrm{H}_{4} \mathrm{NHC}(\mathrm{O}) \mathrm{Cl}\right]\left[\mathrm{WOCl}_{5}\right]$, 1, with key atoms labeled. Thermal ellipsoids are at the 50\% probability level. H-bonds are drawn with dashed lines. Symmetry operations used to generate equivalent atoms: -x, y, z for $\mathrm{Mo}\left(1 \_1\right)$ and the like; $-\mathrm{x}+1,-\mathrm{y}+1 \mathrm{y},-\mathrm{z}+1$ for $\mathrm{W}\left(1 \_1\right)$ and similar atoms.

Figure 2. DFT-calculated structure of 2. M06/C-PCM calculation, $\mathrm{CH}_{2} \mathrm{Cl}_{2}$ as implicit solvent.

Figure 3. Lowest energy DFT-calculated structures of 3 and 4. M06/C-PCM calculations, $\mathrm{CH}_{2} \mathrm{Cl}_{2}$ as implicit solvent.

Figure 4. Proposed mechanism for the formation of $\mathrm{WOCl}_{4}$ complexes from $\mathrm{WCl}_{6}$ and $\mathrm{RCO}_{2} \mathrm{H}\left(\mathrm{R}=\mathrm{CH}_{3}, \mathrm{CCl}_{3}\right)$. Insets: DFT EDF2 optimized geometries for $\mathrm{WCl}_{6}\left(\mathrm{OCOCH}_{3}\right)$ and $\mathrm{WCl}_{5}\left[\mathrm{OCCl}(\mathrm{OH}) \mathrm{CH}_{3}\right]$.

Table 1. Selected bond lengths $(\AA)$ and angles $\left(^{\circ}\right)$ for $\mathbf{1}$.

Table 2. Crystal data and details of the structure refinement for $\mathbf{1}$ 


\section{TABLES}

Table 1. Selected bond distances $(\AA)$ and angles $\left(^{\circ}\right)$ for

1.

\begin{tabular}{ll}
$\mathrm{W}(1)-\mathrm{O}(1)$ & $1.876(13)$ \\
$\mathrm{W}(1)-\mathrm{Cl}(1)$ & $2.308(5)$ \\
$\mathrm{W}(1)-\mathrm{Cl}(2)$ & $2.304(5)$ \\
$\mathrm{W}(1)-\mathrm{Cl}(3)$ & $2.334(5)$ \\
$\mathrm{W}(1)-\mathrm{Cl}(4)$ & $2.329(5)$ \\
$\mathrm{W}(1)-\mathrm{Cl}(5)$ & $2.535(5)$ \\
$\mathrm{C}(1)-\mathrm{O}(2)$ & $1.24(3)$ \\
$\mathrm{C}(1)-\mathrm{Cl}(6)$ & $1.780(19)$ \\
$\mathrm{C}(1)-\mathrm{C}(2)$ & $1.43(3)$ \\
$\mathrm{C}(2)-\mathrm{C}(3)$ & $1.37(3)$ \\
$\mathrm{C}(3)-\mathrm{N}(1)$ & $1.30(3)$ \\
$\mathrm{N}(1)-\mathrm{C}(5)$ & $1.41(3)$ \\
$\mathrm{C}(5)-\mathrm{C}(6)$ & $1.37(3)$ \\
$\mathrm{C}(6)-\mathrm{C}(7)$ & $1.37(3)$ \\
$\mathrm{C}(7)-\mathrm{C}(2)$ & $1.42(2)$ \\
$\mathrm{O}(1)-\mathrm{W}(1)-\mathrm{Cl}(5)$ & $178.8(3)$ \\
$\mathrm{Cl}(1)-\mathrm{W}(1)-\mathrm{Cl}(2)$ & $170.69(19)$ \\
$\mathrm{Cl}(3)-\mathrm{W}(1)-\mathrm{Cl}(4)$ & $170.10(18)$ \\
$\mathrm{Sum}$ at $\mathrm{C}(1)$ & $360(3)$ \\
$\mathrm{Sum}$ aromatic ring & $721(5)$ \\
\hline \multicolumn{1}{c}{$\mathrm{H}-$ bond parameters } & \\
\hline $\mathrm{N}(1)-\mathrm{H}(1)$ & 0.88 \\
$\mathrm{H}(1) \cdots \cdot \mathrm{Cl}(5)$ & 2.39 \\
$\mathrm{~N}(1) \cdots \mathrm{Cl}(5)$ & $3.210(18)$ \\
$\mathrm{N}(3)-\mathrm{H}(1)-\mathrm{Cl}\left(5 \_1\right)$ & 154.7 \\
\hline
\end{tabular}

Table 2. Crystal data and details of the structure refinement for

1.

Formula

$F w$

$\mathrm{C}_{6} \mathrm{H}_{5} \mathrm{Cl}_{6} \mathrm{O}_{2} \mathrm{~W}$

$\mathrm{T}, \mathrm{K}$

519.66

$100(2)$

$\lambda, \AA$

0.71073

Crystal system

Triclinic

Space group

a, $\AA$

$P^{\overline{1}}$

b, $\AA$

6.623(9)

9.937(14)

$c, \AA$

$11.083(15)$

$\alpha,^{\circ}$

$84.027(16)$

$\beta$, ${ }^{\circ}$

$73.750(14)$

$\gamma,{ }^{\circ}$

$72.012(17)$

Cell Volume, $\AA^{3}$

665.9(16)

Z

$D_{c}, \mathrm{~g} \mathrm{~cm}^{-3} \quad 2.592$

$\mu, \mathrm{mm}^{-1} \quad 9.859$

$\mathrm{F}(000) \quad 480$

Crystal size, $\mathrm{mm} \quad 0.16 \times 0.13 \times 0.11$

$\theta$ limits, ${ }^{\circ} \quad 1.91-25.03$

Reflections collected $\quad 5722$

Independent reflections $\quad 2300\left[R_{\text {int }}=0.1030\right]$

Data / restraints /parameters $\quad 2312$ / 54 / 145

Goodness on fit on $\mathrm{F}^{2} \quad 1.014$

$R_{1}(I>2 \sigma(I)) \quad 0.0794$

$w R_{2}$ (all data) 0.1939

Largest diff. peak and hole, e $\AA^{-3} \quad 3.143 /-3.020$ 


\section{FIGURES}

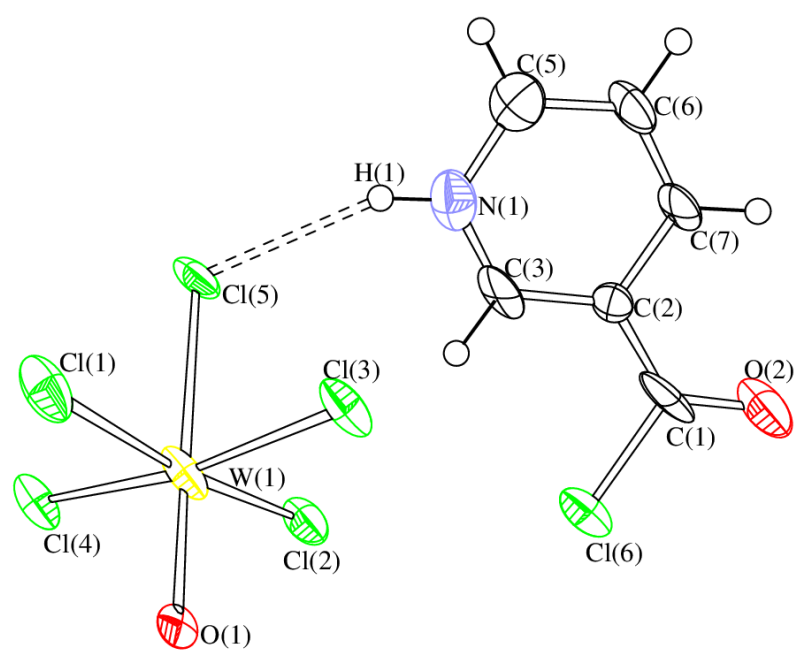

Figure 1. Molecular structure of $\left[\mathrm{C}_{5} \mathrm{H}_{4} \mathrm{NHC}(\mathrm{O}) \mathrm{Cl}\right]\left[\mathrm{WOCl}_{5}\right]$, 1, with key atoms labeled. Thermal ellipsoids are at the $50 \%$ probability level. H-bonds are drawn with dashed lines.

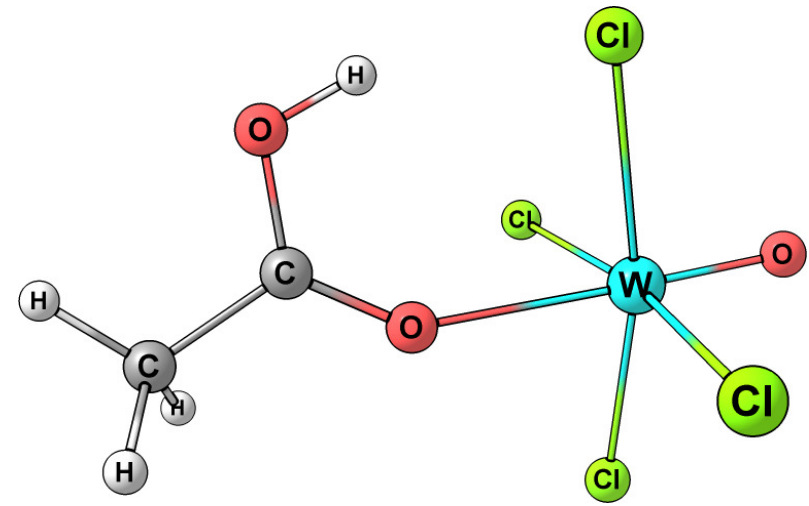

Figure 2. DFT-calculated structure of 2. M06/C-PCM calculation, $\mathrm{CH}_{2} \mathrm{Cl}_{2}$ as implicit solvent.

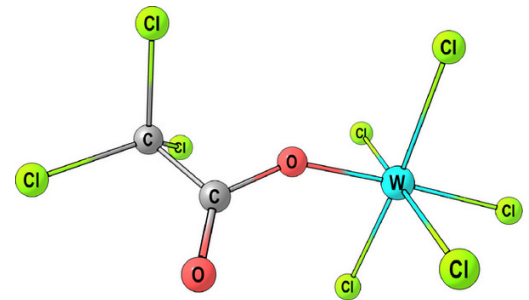

3

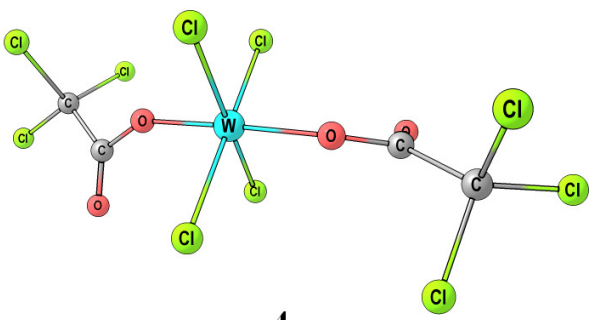

4

Figure 3. Lowest energy DFT-calculated structures of 3 and 4. M06/C-PCM calculations, $\mathrm{CH}_{2} \mathrm{Cl}_{2}$ as implicit solvent. 

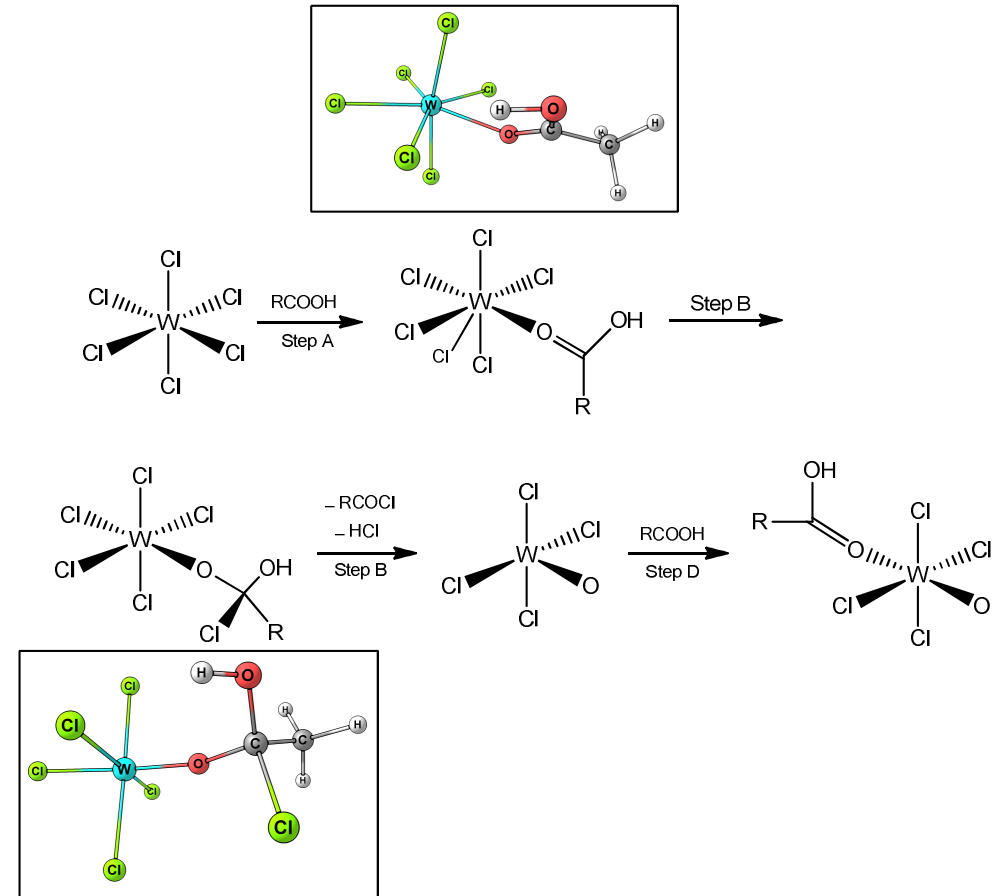

Figure 4. Proposed mechanism for the formation of $\mathrm{WOCl}_{4}$ complexes from $\mathrm{WCl}_{6}$ and $\mathrm{RCO}_{2} \mathrm{H}\left(\mathrm{R}=\mathrm{CH}_{3}, \mathrm{CCl}_{3}\right)$. Insets: DFT EDF2 optimized geometries for $\mathrm{WCl}_{6}\left(\mathrm{OCOCH}_{3}\right)$ and $\mathrm{WCl}_{5}\left[\mathrm{OCCl}(\mathrm{OH}) \mathrm{CH}_{3}\right]$. 